\title{
Late Holocene palaeo-environmental reconstruction and human settlement in the eastern Po Plain (northern Italy)
}

\author{
G. Bianchini ${ }^{\mathrm{a}, *}$, S. Cremonini ${ }^{\mathrm{b}}$, D. Di Giuseppe ${ }^{\mathrm{c}}$, R. Gabusi ${ }^{\mathrm{d}}$, M. Marchesini ${ }^{\mathrm{e}}$, G. Vianello ${ }^{\mathrm{f}}$, L. Vittori Antisari ${ }^{\mathrm{f}}$ \\ ${ }^{a}$ Dipartimento di Fisica e Scienze della Terra, Università di Ferrara, Italy \\ ${ }^{\mathrm{b}}$ Dipartimento di Scienze Biologiche Geologiche Ambientali, Università di Bologna, Italy \\ ${ }^{\mathrm{c}}$ Dipartimento di Scienze Chimiche e Geologiche, Università di Modena e Reggio Emilia, Italy \\ d Soprintendenza Archeologia, Belle Arti e Paesaggio, Città Metropolitana di Bologna, Italy \\ e Dipartimento di Studi Umanistici, Università di Ferrara, Italy \\ f Dipartimento di Scienze e Tecnologie Agro-Alimentari, Università di Bologna, Italy
}

\section{A R T I C L E I N F O}

\section{Keywords:}

Pedostratigraphy

Soil geochemistry

Palynology and ${ }^{14} \mathrm{C}$ datings

Po River palaeo-hydrography

Bronze Age settlement

\begin{abstract}
A B S T R A C T
A sedimentary sequence comprising a Late Bronze age archaeological site located in the alluvial plain between Bologna and Ferrara (Northern Italy) was studied from geochemical, pedological and palynological points of view. Sediment geochemistry (in particular, the high content of $\mathrm{Cr}$ ) indicates the existence of a thin set of Po River deposits coeval to the Bronze Age site, lying among alluvial sediments delivered from the Apennine chain. The soil corresponding to this chronological interval is also characterised by anomalous content of phosphorous and chalcophile elements (mainly $\mathrm{Cu}$ and $\mathrm{Zn}$ ) that are clearly related to anthropogenic activities. The results were critically discussed to reconstruct the geomorphological and regional palaeo-hydrographic settings to support the existence of an unknown buried Po River course active during the late Middle Bronze Age in the southern part of the alluvial plain. The ${ }^{14} \mathrm{C}$ and pollen analyses corroborate this interpretation, also providing clues on the genesis of more superficial peaty horizons. On the whole, the results provide fresh insights on the occurrence of ancient human settlements in the southern Po River alluvial plain.
\end{abstract}

\section{Introduction}

Archaeological research can be greatly improved by multidisciplinary approaches that are useful for understanding landscape development. These studies may include understanding the sedimentary environments and palaeo-hydrological systems, as well as the pedological conditions (Woodward and Huckleberry, 2011; Agatova et al., 2016; Pastor et al., 2016; Simniškytė-Strimaitienè et al., 2017; Horák et al., 2018; Milton, 2018). In particular, in low-lying alluvial basins, settlement and land management were intimately related to the drainage conditions, which regulated food procurement and communication roads.

In this paper, a multidisciplinary investigation, including field observations (analyses of the stratigraphical and pedological sequences), as well as geochemical, radiocarbon and pollen data, has been carried out on a stratigraphic composite section (reaching a depth of approximately $9 \mathrm{~m}$ ) located in the Po Plain between Bologna and Ferrara

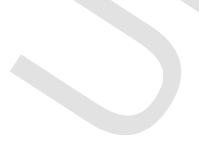

* Corresponding author.

Email address: bncglc@unife.it (G. Bianchini)
(Northern Italy). This investigation implements studies recently carried out with the same approach in neighbouring areas of the Ferrara and Bologna provinces (Bianchini et al., 2014; Vittori Antisari et al., 2016). Notably, the geochemical data are useful for identifying the origins of sediments of the Po Plain, discriminating the contribution of sediment conveyed by the Po River from that delivered by the Apennine rivers, such as the Reno River (Bianchini et al., 2002, 2012). On the other hand, pedological survey could represent a powerful tool to evaluate the development of soil sequences and pollen analysis is crucial for extrapolating environmental variations.

Summarising, the above mentioned data, which are strengthened by radiometric analyses, can provide time-constrained clues on the provenance of the alluvial sediments and on the related depositional facies, providing new insights for reconstructing the palaeo-hydrographic network, and a better understanding of the environmental evolution during the Late Holocene.

Particular emphasis is given to the discrimination of natural (geogenic and pedogenetic) processes and anthropogenic contributions to 
provide insights into human settlements and their development (Vittori et al., 2013). The topic is quite important for archaeological studies at regional scale, as it constrains the existence of a newly discovered Bronze Age site, thus providing insights on the reconstruction of human settlement in northern Italy.

\section{General setting}

\subsection{Geomorphological and geological setting}

The study site $\left(44^{\circ} 43^{\prime} 10^{\prime \prime} \mathrm{N}, 11^{\circ} 30^{\prime} 00^{\prime \prime} \mathrm{E}\right)$ is located $2.5 \mathrm{~km}$ southwest of Malalbergo and $28 \mathrm{~km}$ NNE of Bologna in the lowermost reaches of the Apennine rivers alluvial plain (Fig. 1). The site lies at the bottom of a sub-rounded morphological basin, having a mean diameter of approximately $7 \mathrm{~km}$, and a minimum elevation of $7 \mathrm{~m}$ a.s.l. Only after World War II was the area reclaimed for agricultural practices. It was generated by the juxtaposition of three main alluvial ridges. The most ancient alluvial ridge is on the western side of the basin and pertains to the Roman age Reno River course (Cremonini, 1991). The Renaissance Age (15th-16th century AD) Savena Abbandonato alluvial ridge represents the eastern border (Cremonini, 1992). The northern side of the basin is the present-day Reno River alluvial ridge, activated in the second half of the 18th century AD (Cremonini, 1994). A lower elevation central divide is the small alluvial ridge generated by the medieval age (12th-13th century AD) navigation channel (Canale Navile) died branch (a mill canal called Cà Gioiosa) used for water management in 19th century rice cultivation. Therefore, the current morphology is the result of a complex hydrographic history developed over a wider area since the Roman Age (Cremonini, 1992).

From a geological viewpoint, the site is located in the foreland basin of the Apennine Orogen (Vai and Martini, 2001), a fold-and-thrusts belt dating back to the end of the Oligocene (Fantoni and Franciosi, 2010). During the Plio-Pleistocene, a maximum amount of sedimentation with a thickness of ca. $8 \mathrm{~km}$ took place in the chain foredeep, i.e., the wide Bologna syncline, south of Malabergo (Pieri and Groppi, 1981; Boccaletti and Martelli, 2004; Cerrina Feroni et al., 2002), whereas a chain front started developing between the end of the Miocene and the beginning of the Pliocene (Ghielmi et al., 2010, 2013). This front, known as "Dorsale Ferrarese", is buried in the alluvial plain between Bologna and Ferrara and is still tectonically active, as revealed by recent seismic activity (Galli et al., 2012; Borgatti et al., 2012; Carannante et al., 2015) and deformation of the sedimentary sequence (Cibin and Segadelli, 2009). At approximately $870 \mathrm{Ky} \mathrm{BP}$ (Muttoni et al., 2003) the former marine character changed to prevailing continental conditions, due to the mutual interplay of tectonics and terrigenous sedimentation linked to macro-climatic changes (Amorosi et al., 2014).

\subsection{Archaeological setting}

\subsubsection{Pre-protohistoric evidence in the Po Plain}

Pre-protohistoric research in the whole Po Plain is hampered by a paucity of outcropping archaeological sites, which are mainly buried at various depths within the sedimentary sequence. In fact, the outcrops of the archaeological sites, or their depths in the sedimentary sequence are related to the geomorphological variations induced by the river network evolution, in turn associated with forcing factors such as macro- and micro-scale climate changes throughout the Holocene, sea level fluctuations and tectonic vertical movements (mainly subsidence). For these reasons, the known archaeological sites are unevenly distributed. Outcropping archaeological sites are mainly located in the northern and western parts of the alluvial plain, shaped by the Late-Glacial megafans of the pede-Alpine fringe (Fontana et al., 2014) and southward in the Apennine fringe, in correspondence with coalescent alluvial fans (Castiglioni et al., 1997). By contrast, in the central-eastern parts of the Po Plain (Emilia-Romagna region), which is characterised

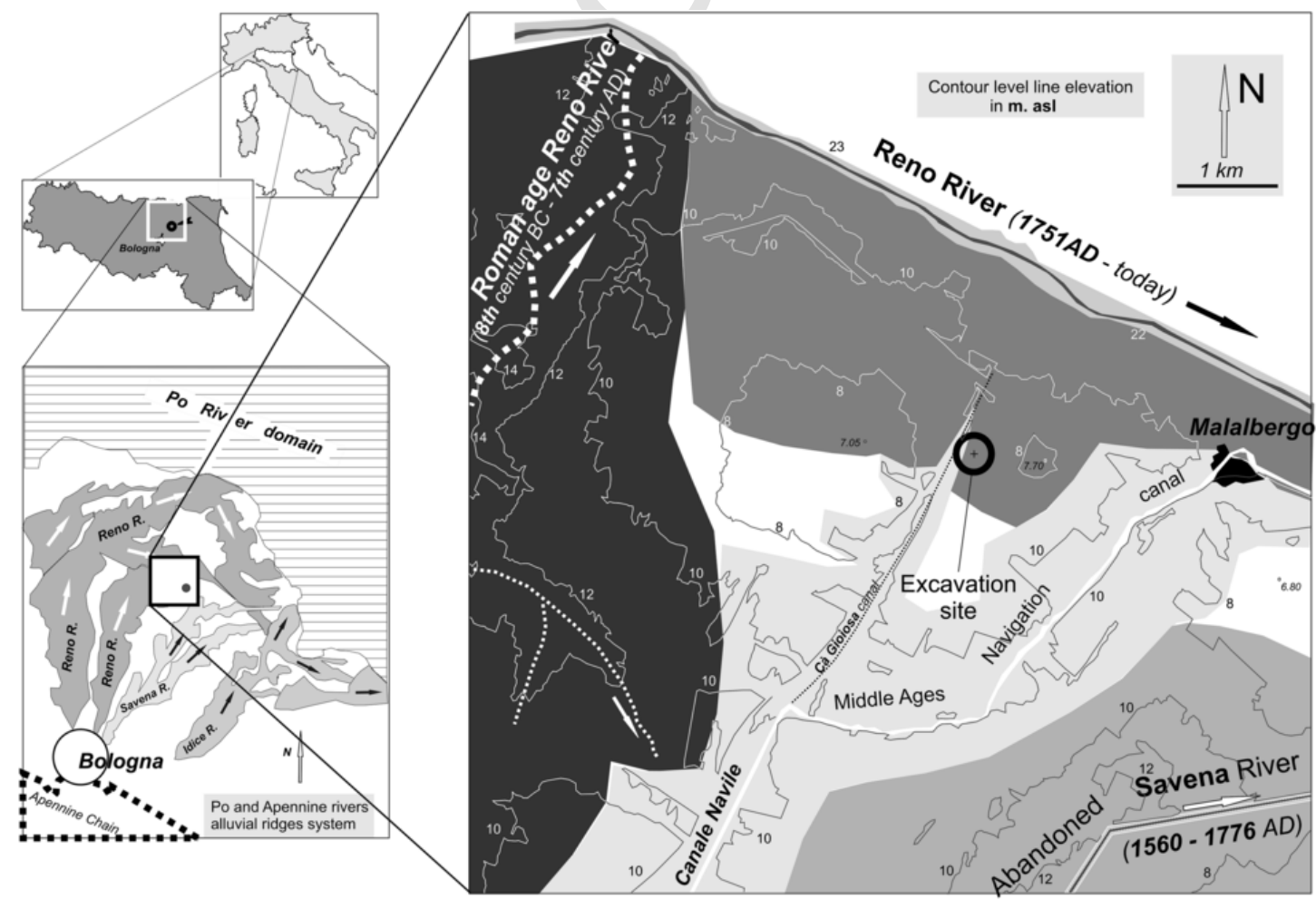

Morphological pertinence areas :

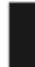

Alluvial ridge flank

Alluvial basin bottom

Fig. 1. The study-site location and related geomorphological setting. The assemblage of the local geomorphological units is detailed in the right panel. 
by Late Holocene alluvial ridges, the known archaeological sites are very rare, due to their deep sedimentary burial. This is the case of the Neolithic Age site of Lugo di Romagna, lying at approximately $14 \mathrm{~m}$ depth below the topographic surface (Steffè, 1999). Notably, in these central and eastern parts of the plain there are even more recent archaeological evidences (e.g. of Roman ages; 2nd century BC-476 CE) that are recorded at burial depths of 7-10 m (Cremonini et al., 2013; Bianchini et al., 2014). This general picture is well illustrated by Cattani (2008). Therefore, in the central-eastern parts of the Po Plain, although the human settlement plausibly existed since the Neolithic (5700-3500 BCE) and Chalcolithic (3500-2500 BCE), most information is limited to the Bronze Ages (2500-1000BCE) due to a lower burial depth of their sites. According to the studies of Cremaschi et al. (2006), the maximum demographic density in the Emilia-Romagna alluvial plain was probably achieved during the Bronze Age, and at its end, a settlement crisis took place (Cardarelli, 2010). In this area, the maxi- mum size of the Bronze age sites corresponded to 2-10 ha, with a concentration of one site per $10 \mathrm{~km}^{2}$ (Cremaschi, 1997). As a consequence of the high demographic density, an impact on the environment occurred during the Bronze Ages (Cremaschi et al., 2006) as shown by pollen analyses, which suggest a severe forest clearance in the Po Plain.

\subsubsection{Archaeological site of Malalbergo}

The archaeological site of Malalbergo (Ponticelli di Malalbergo) is described by Gabusi et al. (2018). The site was discovered at depth during the construction of a gas pipeline. The archaeological excavation was performed in two trenches $22 \times 7 \mathrm{~m}$ wide, lying $60 \mathrm{~m}$ apart (Supplementary Photos 1). The excavation was supervised by Soprintendenza Archeologia dell'Emilia-Romagna during the years 2015-2016. The anthropogenic deposit was found at $7.0 \mathrm{~m}$ depth (Fig. 2, Set E) and had a thickness of 80 to $110 \mathrm{~cm}$. The Malalbergo archaeological site was very rich in ceramic and metallic fragments and in faunal and

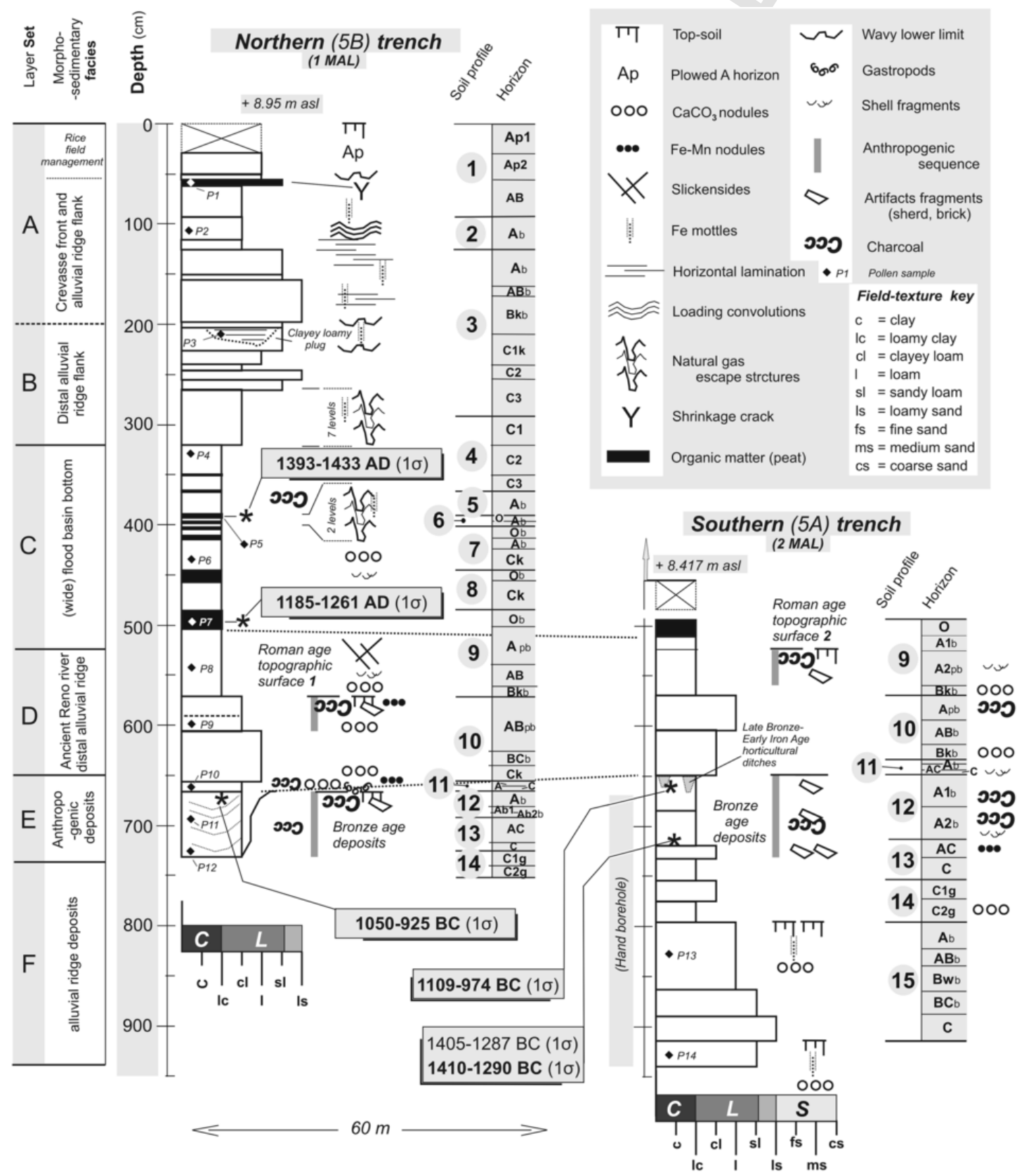

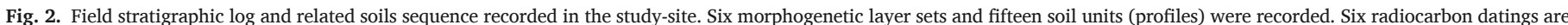
also shown as calibrated years referred to Christian Era. 
malacologic remains. It preserved the evidence of a number of huts and trench structures, indicating the peripheral belt of the site. Four constructive phases were recorded, followed in turn by a final dismantling. The thickness of each phase deposit was 20 to $25 \mathrm{~cm}$ on average. In all settlement phases the orientation of anthropogenic structures was the same, i.e., NW/SE and NE/SW. The most ancient phase was characterised by the existence of rectangular wooden huts built on an overhead deck. In the second phase, a hut was built on an earthen compacted platform. The third phase was recorded by an aggrading layer with faunal remains, heated earth, and coarse sherds, referring to some productive activity, without dwellings. Furthermore, a spoliation ditch of a previously existing wooden fence was also recognised. The fourth phase was characterised by the presence of tree uprooting hollows and a wooden floor built along the bank of an artificial ditch. The metallic objects found in the site (Supplementary Photo 2) consist of big pins, daggers and small rings, recalling those typical of the Terramare Culture spread on Emilia territories west of the Malalbergo site, whereas the ceramic production recalls the Grotta Nuova and Subappenninic cultural facies characterising the Romagna area, east of Malabergo, and central Italy (Cocchi Genick, 1995; Bernabò et al., 1997). Thus, the archaeological materials can be tentatively dated back to the Medium and Late Bronze Ages, and the settlement age of the village could be established between the first half of the 15th century $\mathrm{BC}$ and the second half of the 13th century BC. The discovery of the archaeological site of Malabergo is very important, because only other two Bronze Age sites are known to exist in the easternmost Po River plain, at Coccanile (Balista et al., 2018) and Pilastri di Bondeno (Desantis and Steffè, 1995) that are located at $30 \mathrm{~km} \mathrm{NW}$ and $40 \mathrm{~km} \mathrm{NE}$ of Malabergo, respectively.

\section{Materials and methods}

\subsection{Pedological survey and soil sampling}

In correspondence with the two archaeological trenches, two stratigraphic sections, called 1MAL and 2MAL, respectively, were investigated from sedimentological and pedological points of view. The field observations allowed for the recognition of stratigraphic units and buried soil profiles. In summary, fifteen soil profiles were found in 6 stratigraphic layer-sets (from A to F, Fig. 2), and each soil was described according to Schoeneberger et al. (2012); in particular, 37 horizons in the northern trench (1MAL) and 20 horizons in the southern trench (2MAL) were recognised. Each soil horizon was sampled by collecting approximately $1 \mathrm{~kg}$ of material for analytical investigation.

\subsection{Soil analysis}

The soil samples were air-dried at room temperature, sieved at $2 \mathrm{~mm}$ for physicochemical determinations, and an aliquot of each soil sample was finely ground in an agate mill. Briefly, the $\mathrm{pH}$ was determined via the potentiometric method in a soil/distilled water (1:2.5 ratio $w / v)$ suspension with a glass electrode. The organic carbon (C) and total nitrogen $(\mathrm{N})$ was analysed by an elemental analyser (Carlo Erba 1100) on samples previously treated with $\mathrm{HCl}$ to eliminate carbonates. The determination of total carbonate content was obtained through the volumetric measurement of carbon dioxide developed by carbonate reaction with dilute hydrochloric acid, using a Dietrich-Fruehling apparatus. The grain size investigation was obtained by following the notional classification of Wentworth (1922), by sieving the sandy fraction from the fine $(<63 \mu \mathrm{m})$ fraction and then using wet gravitational separation in deionised water to divide the clay from the silt fraction.

The geochemical analysis of major and trace elements was carried out by X-ray fluorescence (XRF) on powder pellets, using a wavelength-dispersive automated ARL Advant'X spectrometer. Note that the major element analysis (expressed as wt\%) was complemented by the Loss on Ignition (LOI), that is the weight loss recorded after heating at $1050^{\circ} \mathrm{C}$. The repeated analyses of international standards with matrices comparable to the studied samples (e.g., JLK-1, JLS-1, JSD1, JSD2, JSD3; Imai et al., 1996), indicated that precision and accuracy were generally better than $3 \%$ for $\mathrm{Si}, \mathrm{Ti}, \mathrm{Fe}, \mathrm{Ca}$ and $\mathrm{K}$, and $7 \%$ for $\mathrm{Mg}, \mathrm{Al}, \mathrm{Mn}$ and $\mathrm{Na}$. For trace elements (above $10 \mathrm{ppm}$ ), precision and accuracy were generally better than 10\% (Di Giuseppe et al., 2014). Aqua regia extraction was also performed following the procedure proposed by Vittori Antisari et al. (2014), and subsequently analysed by inductively coupled plasma optical emission spectrometry (ICP-OES; Spectro Arcos, Ametek). Geochemical analyses have been calibrated and crosschecked against international reference materials and laboratory internal standards, as described by Vittori Antisari et al. (2014).

\subsection{Radiocarbon dating $\left({ }^{14} \mathrm{C}\right)$}

The ${ }^{14} \mathrm{C}$ dating on organic matter (peat) and charcoal samples was performed at the University of Lecce-CEDAD (Centre for Dating and Diagnostic) Laboratory, Italy, by high-resolution accelerator mass spectrophotometry (AMS). In particular, the samples were collected in two O horizons of soil profiles 6 and 9 , as well as in charcoals collected at the top and at the bottom of soil 12 (Fig. 2). The method described by Calcagnile et al. (2005) and Fiorentino et al. (2008) included a preliminary treatment of the samples, following a multi-step protocol that removed sources of contamination and converted material in graphite, the suitable form for AMS analyses. The ${ }^{13} \mathrm{C} /{ }^{12} \mathrm{C}$ ratio and the ${ }^{14} \mathrm{C}$ counts recorded in the investigated samples were compared with those of reference materials (e.g., the fossil wood IAEA C4) of known isotopic composition supplied by the International Atomic Energy Agency (IAEA). The conventional radiocarbon ages were calculated according to Stuiver and Polach (1977) and then converted to calendar ages using the latest internationally accepted calibration data set (INTCAL04) (Blackwell et al., 2006) and the OxCal 3.1 software (Bronk Ramsey, 2001).

\subsection{Pollen analysis}

Palynological analysis was carried out on 15 samples (Fig. 2) collected in the $1 \mathrm{MAL}$ and in the 2MAL sequences by applying a methodology tested by Lowe et al. (1996) and Marchesini et al. (2017). The method includes the following phases: approximately $8-10 \mathrm{~g}$ was treated in $10 \%$ Na-pyrophosphate to deflocculate the sediment matrix. A Lycopodium spores tablet was added to calculate pollen concentration (expressed as pollen grains per gram $=\mathrm{p} / \mathrm{g}$ ). The sediment residue was subsequently washed through $7-\mu \mathrm{m}$ sieves, then suspended in $10 \%$ $\mathrm{HCl}$ to remove calcareous material and subjected to Erdtman acetolysis; the heavy liquid separation method was subsequently performed using Na-metatungstate hydrate of s.g. 2.0 and centrifugation at $2000 \mathrm{rpm}$ for $20 \mathrm{~min}$. Following this procedure, the retained fractions were treated with $40 \% \mathrm{HF}$ for $24 \mathrm{~h}$ and then the sediment residue was washed previously in distilled water and after in ethanol with glycerol; the final residue was desiccated and mounted on slides by glycerol jelly and finally sealed with paraffin. Identification of the samples was performed at $\times 1000$ light microscope magnification (ocular $\times 10$ and objective $\times 100$ ). The determination of the pollen grains was based on the pollen reference library of our laboratory, atlases and a vast amount of specific morpho-palynological bibliographies. The names of the families, genus and species of plants conform to the classifications of Italian Flora proposal by Pignatti (1982) and European Flora (Tutin et al., 2001). The pollen terminology is based on Berglund and Ralska-Jasiewiczowa (1986), Faegri and Iversen (1989) and Moore et al. (1991) with slight modifications that tend to simplify the nomenclature of plants. 


\subsection{Statistical analysis}

The Principal Component Analysis (PCA) was used for a data statistical treatment, in order to highlight analogies and differences between distinct samples and sample groups (Gangopadhyay et al., 2001). This technique is useful to synthesise the information provided by a large number of measured parameters to a smaller number of variables called principal components (PCs), which are grouped variables that have similar behaviours. PCA was carried out following the method proposed by Corbeau et al. (2015). After data normalization, PCA was applied on major elements $\left(\mathrm{SiO}_{2}, \mathrm{TiO}_{2}, \mathrm{Al}_{2} \mathrm{O}_{3}, \mathrm{Fe}_{2} \mathrm{O}_{3}, \mathrm{MgO}, \mathrm{CaO}, \mathrm{Na}_{2} \mathrm{O}, \mathrm{K}_{2} \mathrm{O}, \mathrm{P}_{2} \mathrm{O}_{5}\right)$, trace elements (Cr, Co, Cu, Ni, V, Zn, Zr) and LOI, using the Statistical Package for Social Sciences - SPSS version 17. The factor axes were rotated applying the Varimax method.

\section{Results}

\subsection{Stratigraphic sequence and soil survey}

The stratigraphic and pedological sequences are shown in Fig. 2. The Set A mainly included distal alluvial ridge facies and crevasse deposits linked to the present-day Reno River and is characterised by a coarsening upward sequence. In particular, the uppermost $60 \mathrm{~cm}$ of sediments are derived from rice cultivation, as documented in historical cartography (Pasini, 1958). The Set B comprised distal alluvial ridge flank deposits characterised by thin layers. The Set $\mathrm{C}$ grouped only fine-grained material due the settling down of overbank sediments in an alluvial basin bottom; within this set, eight peat levels are interbedded in the loamy clayey sequence, suggesting the low energy characterising this environment and its remoteness from the riverbeds. The Set D corresponded to alluvial ridge and large crevasse distal facies and records at least - two Roman Age topographic surfaces. The Set E collected the anthropogenic stratigraphic units pertaining to the Bronze Age human settlement. The Set F included overbank and crevasse deposits of alluvial ridge facies predating the Bronze Age.

Within the above mentioned stratigraphic sets, 15 soil profiles have been recognised, and the related pedological and physicochemical properties are reported in Table 1.

As expected, soils 1, 2 and 3 showed a high variability of silt and sand content, as well as high carbonate content, ranging from 109 to $170 \mathrm{~g} \mathrm{~kg}^{-1}$, with an increase in soil 3 characterised by the development of Bk and C1k horizons. The soil 4 profile was characterised by a homogeneous silty-loam grain size. Below, the A horizon of Soil 5 was also characterised by low amounts of sand and the presence of organic $\mathrm{C}$ content. In these five soil profiles, the $\mathrm{pH}$ values ranged between 7.4 and 8.2 , the $\mathrm{C}_{\text {org }}$ content ranged from 10.4 to $29.2 \mathrm{~g} \mathrm{~kg}^{-1}$, and the Munsell color varied between $2.5 \mathrm{Y} 6 / 1$ and $2.5 \mathrm{Y} 6 / 8$. In organic horizons characterising the soils $6,7,8$ and 9, mucky peats and in some cases, shell fragments were recognised. These $\mathrm{O}$ horizons showed low $\mathrm{pH}$ values, ranging from 3.4 to 6.4 , while the horizons below had neutral/sub-alkaline values. Notably, the higher content of organic carbon $\left(116-212 \mathrm{~g} \mathrm{~kg}^{-1}\right)$ has been measured in the $\mathrm{O}$ horizons of soil 9 , characterised by a Bk horizon containing carbonate concretions (CAC). The soils 10, 11, 12, 13 were characterised by the presence of charcoal $(\mathrm{CH})$. Soils 10 and 11 showed low sand content with increasing amounts of clay content. Soil 12 had a silty texture, and contained pottery. Soil 13 was characterised by a higher sand content and the presence of iron-manganese concretions (FMC). Furthermore, soil 14 was characterised only by $\mathrm{Cg}$ horizons marked by hydromorphic condition (gley features) and high sand content. Finally, soil 15 was well developed and characterised by a high sand content and a low amount of organic matter.

\subsection{Geochemical data}

The analyses by XRF of major and trace elements (expressed in $\mathrm{wt} \%$ and $\mathrm{mg} \mathrm{kg}^{-1}$, respectively) of all soil horizons from the two stratigraphic sections (1MAL and 2MAL) are reported in Supplementary Tables 1 and 2, whereas Supplementary Table 3a shows the three components (PC1, PC2 and PC3) obtained by PCA processing. PC1 has a positive loading for all variables except for $\mathrm{SiO}_{2}, \mathrm{CaO}, \mathrm{Na}_{2} \mathrm{O}$ and $\mathrm{Zr}$. PC2 groups the variables $\mathrm{P}_{2} \mathrm{O}_{5}, \mathrm{Cu}, \mathrm{Ni}$ and $\mathrm{Zn}$. PC3 has a high-positive loading for $\mathrm{SiO}_{2}$ and a high-negative loading for LOI. The scores obtained from the factor analysis have been plotted on a binary diagram (PC1 vs. PC2) to evaluate geochemical analogies and differences between the distinct soil horizons (Fig. 3a). In this diagram, a homogeneous grouping of soil samples along a trend line $y=0.3 \times-0.2$ can be observed, with the exception of four samples, referring to Soil 12 . These outliers have a distinct origin with respect to the other samples.

To decipher these differences, it has to be observed that $\mathrm{SiO}_{2}$ and the $\mathrm{SiO}_{2} / \mathrm{Al}_{2} \mathrm{O}_{3}$ ratio of samples pertaining to the Soil 12 indicate a comparative enrichment of quartz (over feldspars and clay minerals). Furthermore, Soil 12 is depleted in $\mathrm{CaO}$, (accordingly with its low $\mathrm{CaCO}_{3}$ abundance (Table 2). It is interesting to note that most samples plotted on the $\mathrm{Cr}$ vs. $\mathrm{Al}_{2} \mathrm{O}_{3}$ diagram (Fig. $3 \mathrm{~b}$ ) perfectly conform to the composition of the Reno River alluvial sediments, with the exception of samples of Soil 12, which recall the composition of Po River sediments. Another peculiarity that characterises Soil 12 is the high content of phosphorous (expressed as $\mathrm{P}_{2} \mathrm{O}_{5}$ ) compared to the percentage of $\mathrm{Al}_{2} \mathrm{O}_{3}$ (Fig. 3c). These outliers are also characterised by high $\mathrm{Cu}$ and $\mathrm{Zn}$ contents (Fig. $3 \mathrm{~d}$ ).

The enrichment of chalcophile elements such as copper $(\mathrm{Cu})$ and zinc (Zn), suggesting an anthropogenic contribution, can also be observed by aqua regia extraction and ICP-OES determination of trace elements (Supplementary Table 4S; Fig. 4). Despite the different analytical approach, ICP-OES confirms that samples of Soil 12 are completely different from the other ones, having very a high content of $\mathrm{Cu}, \mathrm{Zn}$, and $\mathrm{P}$ (Fig. 4a and b). The aqua regia method also highlighted that Soil 12 is comparatively enriched in Sn and Cd (Fig. 4c and d), suggesting the local occurrence of ancient metallurgical activities.

\subsection{Radiocarbon dating $\left({ }^{14} \mathrm{C}\right)$}

The ${ }^{14} \mathrm{C}$ dating of both organic matter (peat) and charcoal retrieved from 6 soil samples at the different depths of the investigated stratigraphy are reported in Table 2 . The deepest samples, pertaining to the top of soil 13 and the bottom of soil 12 (i.e., at the base of the Bronze Age deposit), have been characterised by two independent datings, yielding (at $1 \sigma$ confidence level) the following results: 1410-1290 BCE and 1405-1287 BCE, respectively. Two independent samples from the top of soil 12 (i.e., collected at the top of the Bronze Age level) provided the results of 1109-974BCE and 1050-925BCE, respectively. The two peat layers (pertaining to soils 6 and 9, respectively) are dated between 1393 and $1433 \mathrm{CE}$ and 1185-1261 CE, respectively. This indicates that the archaeological site dates back to the end of the Middle Bronze Age, whereas the youngest peats were generated at the end of Middle Ages. Noteworthy, the radiochronometric age of the archaeological site is consistent with the recorded chronotypological evidence.

\subsection{Pollen analysis}

The pollen investigation was performed on a subset of samples representative of distinct deposits. In all samples, the pollen grains were found to be well preserved, and the amount of reworked pollen (secondary) was very low. In total, 3151 pollen grains were counted from 15 samples. The pollen flora consisted of 120 types (36 trees, shrubs, lianes and 84 herbs) that were summarised in Fig. 5. Herbaceous pollen prevailed in all of the investigated sequences. In the strati- 
Table 1

Physico-chemical characters of soils of the Malalbergo stratigraphic sections.

\begin{tabular}{|c|c|c|c|c|c|c|c|c|c|c|c|c|}
\hline & $\begin{array}{l}\text { Soil } \\
\text { profile }\end{array}$ & Horizon & Depth & $\begin{array}{l}\text { Color } \\
\text { (dry) } \\
\text { Munsell's } \\
\text { chart }\end{array}$ & $\begin{array}{l}\mathrm{pH} \\
\left(\mathrm{H}_{2} \mathrm{O}\right)\end{array}$ & $\begin{array}{l}\text { Total } \\
\mathrm{CaCO}_{3}\end{array}$ & Textur & & & $\mathrm{C}_{\text {org }}$ & Accumulation of mate & ials \\
\hline & & & & & & & Sand & Silt & Clay & & $\begin{array}{l}\text { Concentrations and } \\
\text { fragments** }\end{array}$ & $\begin{array}{l}\text { Artifacts and } \\
\text { human derived } * * * *\end{array}$ \\
\hline & & & $\mathrm{cm}$ & & & $\mathrm{g} \mathrm{kg}^{-1}$ & & & & & & \\
\hline \multirow{37}{*}{$\begin{array}{l}1 \mathrm{MAL} \text { - Northern } \\
\text { trench }\end{array}$} & 1 & Ap1 & $0-30$ & $2.5 Y 6 / 2$ & 7.4 & 128 & 49 & 791 & 160 & 29.2 & - & \\
\hline & & Ap2 & $30-57$ & $2.5 Y 6 / 3$ & 7.4 & 125 & 50 & 789 & 161 & 29.1 & & \\
\hline & & $\mathrm{AB}$ & 57-97 & $2.5 Y$ 6/8 & 8.0 & 109 & 27 & 830 & 143 & 14.0 & & \\
\hline & 2 & A & $97-124$ & $2.5 Y 6 / 3$ & 8.1 & 112 & 17 & 824 & 159 & 26.9 & & \\
\hline & 3 & A & $124-162$ & $2.5 Y 6 / 2$ & 8.1 & 136 & 100 & 772 & 128 & 28.5 & & \\
\hline & & $\mathrm{AB}$ & $162-172$ & $2.5 Y$ 6/4 & 8.0 & 136 & 136 & 707 & 157 & 18.6 & 7 & \\
\hline & & $\mathrm{Bk}$ & $172-209$ & $2.5 Y 5 / 6$ & 8.1 & 168 & 93 & 748 & 159 & 16.1 & & \\
\hline & & $\mathrm{C} 1 \mathrm{k}$ & $209-240$ & $2.5 Y 6 / 2$ & 8.2 & 170 & 193 & 645 & 162 & 16.0 & & \\
\hline & & $\mathrm{C} 2$ & $240-254$ & $2.5 Y 6 / 2$ & 8.1 & 132 & 102 & 748 & 150 & 16.0 & & \\
\hline & & C3 & 254-291 & $2.5 Y 6 / 6$ & 8.2 & 143 & 262 & 578 & 160 & 10.4 & & \\
\hline & 4 & $\mathrm{AC}$ & $291-320$ & $2.5 Y 6 / 2$ & 8.1 & 132 & 12 & 839 & 149 & 24.2 & & \\
\hline & & $\mathrm{C} 1$ & $320-349$ & $2.5 Y 5 / 6$ & 8.0 & 132 & 18 & 793 & 189 & 22.1 & & \\
\hline & & $\mathrm{C} 2$ & $349-366$ & $2.5 Y$ 6/6 & 8.0 & 132 & 11 & 820 & 169 & 20.8 & & \\
\hline & 5 & A & $366-384$ & $2.5 Y$ 6/1 & 7.8 & 109 & 14 & 753 & 233 & 27.0 & & $\mathrm{CH}$ \\
\hline & 6 & $\mathrm{O}$ & $384-392$ & $2,5 Y 2.5 / 1$ & 3.4 & 0 & $441 *$ & $294 *$ & $265^{*}$ & 114.3 & MPT & \\
\hline & & A & $392-400$ & $2.5 Y$ 5/1 & 6.5 & 11,2 & 61 & 738 & 201 & 46.4 & & \\
\hline & 7 & $\mathrm{O}$ & $400-412$ & $2.5 Y 3 / 1$ & 5.5 & 0 & $439 *$ & $300^{*}$ & $261^{*}$ & 124.2 & MPT & \\
\hline & & A & $412-423$ & $2.5 Y$ 6/1 & 7.2 & 138 & 57 & 736 & 207 & 36.8 & & \\
\hline & & $\mathrm{Ck}$ & $423-444$ & $2.5 Y$ 6/1 & 7.5 & 150 & 10 & 791 & 199 & 30.0 & CAC & \\
\hline & 8 & $\mathrm{O}$ & $444-452$ & $2.5 Y 2.5 / 1$ & 6.4 & 69,2 & $395^{*}$ & $384 *$ & $221^{*}$ & 101.7 & MPT- SFB & \\
\hline & & $\mathrm{Ck}$ & $452-477$ & $2.5 Y$ 6/1 & 7.7 & 154 & 16 & 826 & 158 & 29.2 & & \\
\hline & 9 & $\mathrm{O}$ & $485-503$ & $2.5 Y 2.5 / 1$ & 4.2 & 0 & $402^{*}$ & $353^{*}$ & $245^{*}$ & 116.4 & MPT & \\
\hline & & Ap & 503-538 & $2.5 Y$ 6/1 & 7.3 & 71,4 & 17 & 667 & 316 & 27.4 & & \\
\hline & & $\mathrm{AB}$ & $538-560$ & $2.5 Y 6 / 3$ & 7.7 & 132 & 111 & 600 & 289 & 15.0 & SFB & \\
\hline & & $\mathrm{Bk}$ & $560-570$ & $2.5 Y$ 6/4 & 7.6 & 174 & 62 & 674 & 264 & 22.4 & CAC & \\
\hline & 10 & $\mathrm{ABp}$ & $570-625$ & $2.5 Y$ 5/1 & 7.9 & 103 & 32 & 665 & 303 & 26.4 & FMC & $\mathrm{CH}$ \\
\hline & & $\mathrm{BC}$ & $625-638$ & $2.5 Y 7 / 1$ & 8.1 & 91,5 & 14 & 626 & 360 & 23.3 & & \\
\hline & & $\mathrm{Ck}$ & $638-655$ & $2.5 Y 6 / 3$ & 8.0 & 170 & 58 & 619 & 323 & 23.9 & CAC & \\
\hline & 11 & A & $655-660$ & $2.5 Y 5 / 1$ & 7.9 & 58,1 & 50 & 632 & 318 & 28.3 & FMC & $\mathrm{CH}$ \\
\hline & & $\mathrm{C}$ & $660-665$ & $2.5 Y 7 / 1$ & 8.3 & 75,9 & 40 & 680 & 280 & 22.9 & SFB - CAC & \\
\hline & 12 & A & $665-681$ & $2.5 Y 7 / 1$ & 7.8 & 13,4 & 158 & 639 & 203 & 28.2 & & $\mathrm{AB}-\mathrm{AP}-\mathrm{CH}$ \\
\hline & & $\mathrm{AB} 1$ & $681-686$ & $2.5 Y 7 / 1$ & 7.7 & 11,2 & 190 & 624 & 186 & 25.2 & & $\mathrm{AB}-\mathrm{CH}$ \\
\hline & & $\mathrm{AB} 2$ & $686-691$ & $7.5 Y R$ 8/4 & 7.7 & 11,2 & 140 & 672 & 188 & 24.8 & & AB. AP \\
\hline & 13 & $\mathrm{AC}$ & $691-716$ & $2.5 Y 5 / 6$ & 8.3 & 87,1 & 300 & 530 & 170 & 15.5 & FMC & $\mathrm{CH}$ \\
\hline & & $\mathrm{C}$ & $716-724$ & $2.5 Y$ 5/6 & 8.4 & 91,5 & 380 & 451 & 169 & 9,90 & FMC & \\
\hline & 14 & $\mathrm{C} 1 \mathrm{~g}$ & $724-739$ & $\begin{array}{l}\text { GLEY1 5/ } \\
5 \text { GY }\end{array}$ & 8.5 & 89,3 & 541 & 288 & 171 & 5.30 & & \\
\hline & & $\mathrm{C} 2 \mathrm{~g}$ & $739-750$ & GLEY1 5/ & 8.5 & 89,3 & 441 & 395 & 164 & 12.7 & & \\
\hline \multirow{20}{*}{$\begin{array}{l}2 \text { MAL Southern } \\
\text { trench }\end{array}$} & 9 & $\mathrm{O}$ & $493-510$ & $2.5 Y 2.5 / 1$ & 6.0 & 0 & $230 *$ & $499 *$ & $271^{*}$ & 212.8 & MPT & \\
\hline & & A1p & $510-525$ & $2.5 Y$ 6/1 & 7.7 & 80.3 & 25 & 719 & 256 & 35.4 & & \\
\hline & & A2p & $525-536$ & $2.5 Y$ 6/2 & 6.8 & 121 & 87 & 753 & 160 & 49.6 & SFB & \\
\hline & & $\mathrm{Bk}$ & $536-548$ & $2.5 Y 6 / 4$ & 7.4 & 182 & 69 & 746 & 185 & 40.0 & CAC & \\
\hline & 10 & Ap & $548-576$ & $2.5 Y$ 5/1 & 7.7 & 101 & 33 & 833 & 134 & 31.9 & & $\mathrm{AB}-\mathrm{CH}$ \\
\hline & & $\mathrm{AB}$ & $576-600$ & $2.5 Y 6 / 1$ & 7.8 & 106 & 51 & 807 & 142 & 21.1 & & \\
\hline & & $\mathrm{Bk}$ & $600-616$ & $2.5 Y$ 6/3 & 7.7 & 177 & 55 & 787 & 158 & 18.3 & CAC & \\
\hline & 11 & A & $616-633$ & $2.5 Y$ 5/1 & 7.8 & 59.7 & 47 & 710 & 243 & 27.9 & & \\
\hline & & $\mathrm{AC}$ & $633-643$ & $2.5 Y$ 6/1 & 7.7 & 77.4 & 45 & 683 & 272 & 23.4 & & \\
\hline & & C & $643-648$ & $2.5 Y 7 / 2$ & 7.6 & 74.8 & 69 & 715 & 216 & 25.5 & SFB & \\
\hline & 12 & $\mathrm{~A} 1$ & $648-681$ & $2.5 Y$ 6/1 & 7.6 & 11.8 & 146 & 657 & 197 & 27.3 & & $\mathrm{CH}$ \\
\hline & & $\mathrm{A} 2$ & $681-713$ & $2.5 Y 7 / 2$ & 7.6 & 12.3 & 158 & 637 & 205 & 28.8 & SFB & $\mathrm{CH}$ \\
\hline & 13 & AC & $713-730$ & $2.5 Y 5 / 6$ & 7.6 & 99.3 & 301 & 507 & 192 & 17.2 & FMC & $\mathrm{CH}$ \\
\hline & & $\mathrm{C}$ & $730-753$ & $2.5 Y 6 / 5$ & 7.8 & 95.4 & 345 & 502 & 153 & 14.7 & & \\
\hline & 14 & $\mathrm{C} 1 \mathrm{~g}$ & $753-772$ & $\begin{array}{l}\text { Gley1 7/ } \\
5 \mathrm{G}\end{array}$ & 7.8 & 90.4 & 411 & 470 & 119 & 13.7 & & \\
\hline & & $\mathrm{C} 2 \mathrm{~g}$ & $772-795$ & $\begin{array}{l}\text { Gley2 7/ } \\
\text { 5BG }\end{array}$ & 7.8 & 88.9 & 491 & 432 & 77 & 14.6 & CAC & \\
\hline & 15 & A & $795-822$ & $5 Y$ 6/1 & 7.7 & 44,6 & 512 & 402 & 86 & 15.2 & & \\
\hline & & $\mathrm{AB}$ & $822-839$ & $5 Y 7 / 2$ & 7.7 & 45,7 & 498 & 403 & 99 & 13.4 & & \\
\hline & & Bw & 839-864 & $5 Y$ 6/2 & 7.7 & 49.9 & 497 & 399 & 104 & 9.70 & & \\
\hline & & $\mathrm{BC}$ & $864-883$ & $2.5 Y 6 / 6$ & 7.7 & 55.8 & 522 & 401 & 77 & 5.10 & & \\
\hline
\end{tabular}

* Determination performed on the calcination residue $\left(550^{\circ} \mathrm{C}\right)$.

** $\mathrm{CAC}=$ carbonate concretions $-\mathrm{FMC}=$ iron-manganese concretions $-\mathrm{MPT}=$ mucky peat $-\mathrm{SFB}=$ shell fragments 
*** $\mathrm{AB}=$ bricks $-\mathrm{AP}=$ pottery $-\mathrm{CH}=$ charcoal.
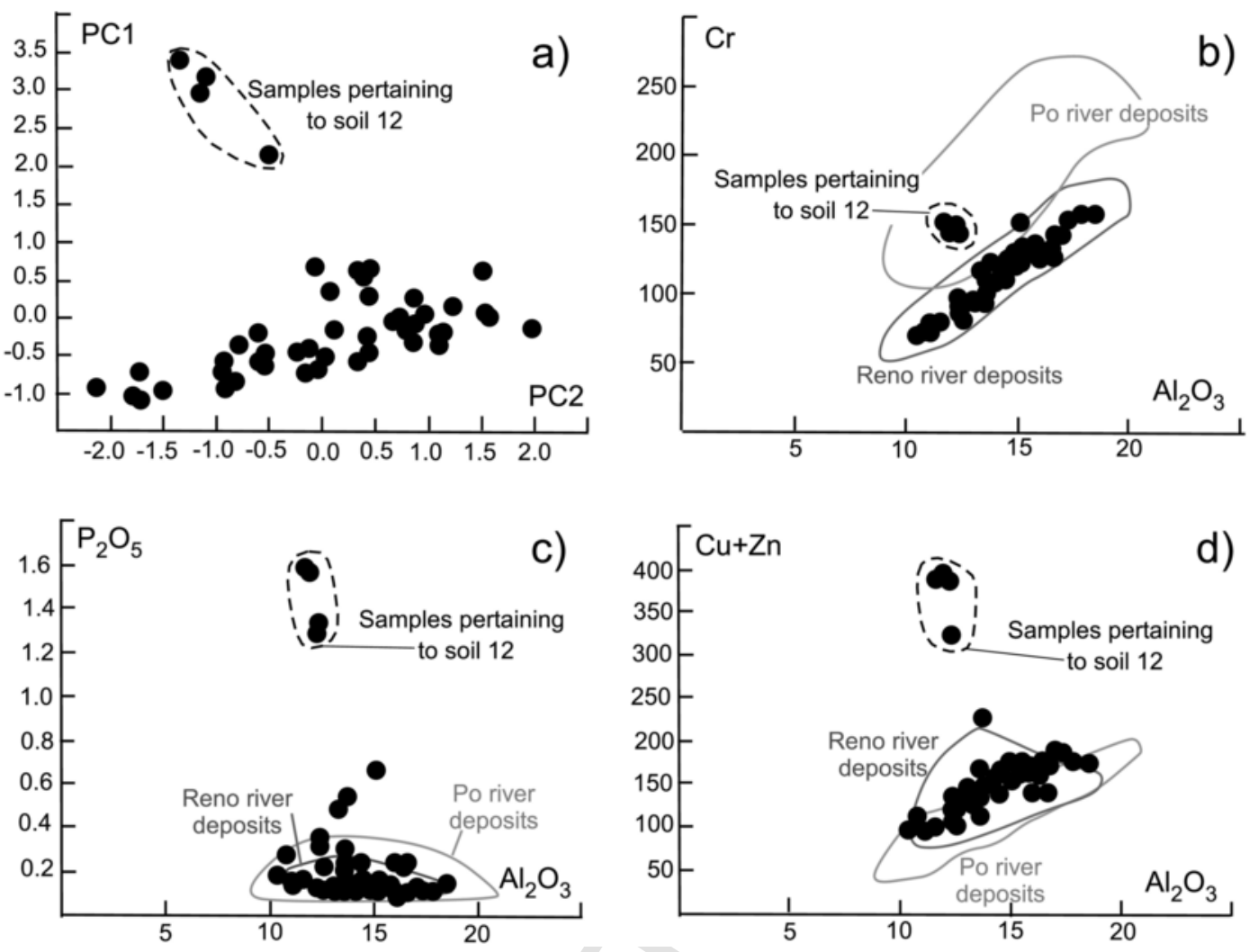

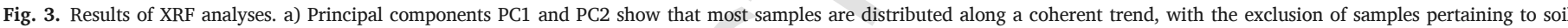

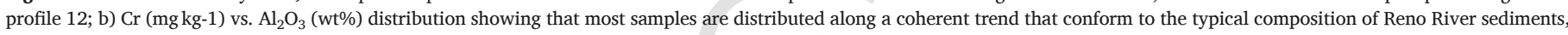

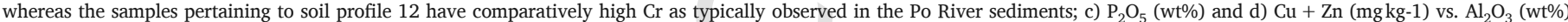

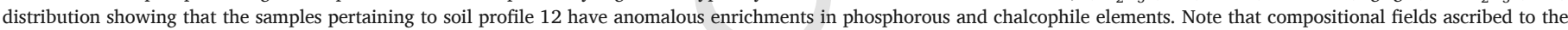
Po and Reno Rivers sediments are based on the data set provided by Bianchini et al. (2012, 2013).

Table 2

${ }^{14} \mathrm{C}$ dating of peat levels and charcoal samples.

\begin{tabular}{|c|c|c|c|c|c|c|}
\hline Trench & Soil & Horizon & Conventional ${ }^{14} \mathrm{C}$ age uncal. y $\mathrm{BP}$ & Age cal. y CE $(1 \sigma)$ & Age cal. y CE $(2 \sigma)$ & Material \\
\hline $1 \mathrm{MAL}$ & 6 & $\mathrm{O}$ & $536 \pm 45$ & $\begin{array}{l}(48.7 \%) \\
1393-1433 \mathrm{CE}\end{array}$ & $\begin{array}{l}(58.5 \%) \\
1383-1445 \mathrm{CE}\end{array}$ & $\begin{array}{l}\text { Organic matter } \\
\text { (peat) }\end{array}$ \\
\hline $1 \mathrm{MAL}$ & 9 & $\mathrm{O}$ & $821 \pm 45$ & $\begin{array}{l}(68.2 \%) \\
1185-1261 \mathrm{CE}\end{array}$ & $\begin{array}{l}(91.0 \%) \\
1151-1082 \mathrm{CE}\end{array}$ & $\begin{array}{l}\text { Organic matter } \\
\text { (peat) }\end{array}$ \\
\hline $1 \mathrm{MAL}$ & 12 & A & $2838 \pm 45$ & $\begin{array}{l}(78.7 \%) \\
1050-925 \text { ВСЕ }\end{array}$ & $\begin{array}{l}(92.9 \%) \\
1127-894 \text { BCE }\end{array}$ & Charcoal \\
\hline 2 MAL & 12 & $\mathrm{~A} 1$ & $2860 \pm 45$ & $\begin{array}{l}(63.7 \%) \\
1109-974 \text { BCE }\end{array}$ & $\begin{array}{l}(90.3 \%) \\
1130-909 \text { ВСЕ }\end{array}$ & Charcoal \\
\hline $2 \mathrm{MAL}$ & 12 & A2 & $3078 \pm 45$ & $\begin{array}{l}(68,2 \%) \\
1405-1287 \text { BCE }\end{array}$ & $\begin{array}{l}(95,4 \%) \\
1432-1222 \text { BCE }\end{array}$ & Charcoal \\
\hline 2MAL & 13 & AC & $3085 \pm 45$ & $\begin{array}{l}(68.2 \%) \\
1410-1290 \text { BCE }\end{array}$ & $\begin{array}{l}(95.4 \%) \\
1435-1225 \text { BCE }\end{array}$ & Charcoal \\
\hline
\end{tabular}

graphic interval of soils 9-14, the pollen of both meadows and pastures showed a high frequency, and it is possible to note that cereal pollens increased in soils 10 (Roman Age) and 11 (Bronze/Iron Age). On the other hand, a high frequency of hygro-hydro-elophytes pollen was observed in the stratigraphic interval of soils 5-8. Meadow and pasture pollens prevailed in the stratigraphic interval of soils 1 and 4, with a progressive increase of spontaneous edible herbs. The arboreal pollen, although subordinate, is indicative of the existing environmental conditions. Quercetum taxa pollen prevailed (with respect to conifers) in the stratigraphic intervals of soils 1-4 and 10-14, whereas Salix decidedly prevailed in the stratigraphic interval of soils 6-8.

\section{Discussion}

\subsection{Palaeo-hydrography and environmental evolution}

The observed stratigraphy indicates a succession of mutually superimposed local alluvial basins, generated by the changing location of the alluvial ridges triggered by several river avulsions. Since at least the Roman Age, a wide basin existed eastward from the ancient Reno River (Fig. 2, Set D). This basin was completely open towards the east and north for some tens of kilometres up to the Idice River and the Roman age Po River (Castiglioni et al., 1997). This can explain why the sedimentation was substantially missing after the Roman age up to the be- 


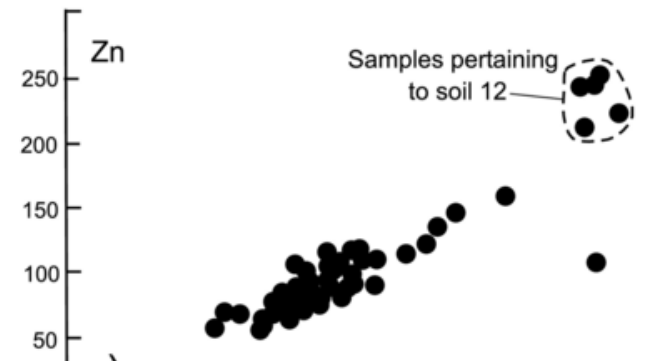

a)

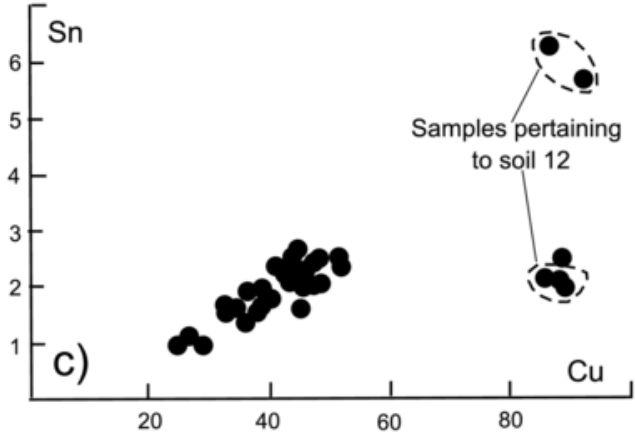

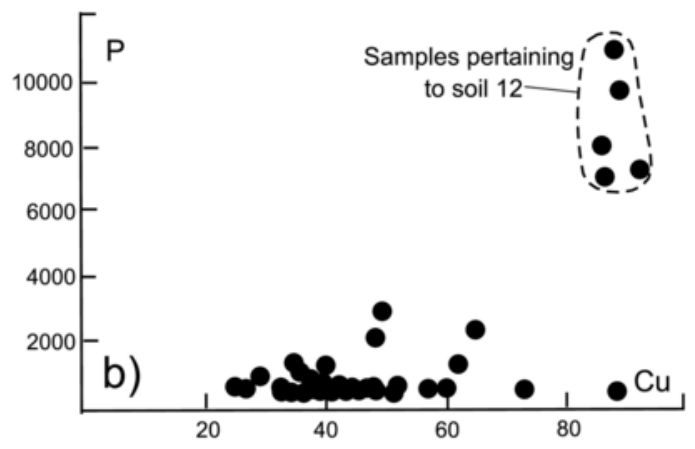

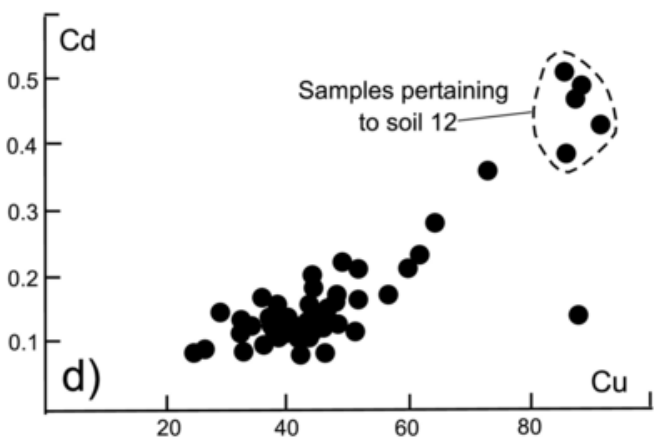

Fig. 4. ICP-OES analyses (expressed in mg kg-1) showing that samples pertaining to soil profile 12 are comparatively enriched in $\mathrm{Cu}, \mathrm{Zn}, \mathrm{P}$, $\mathrm{Cd}$ and sometimes also in Sn.

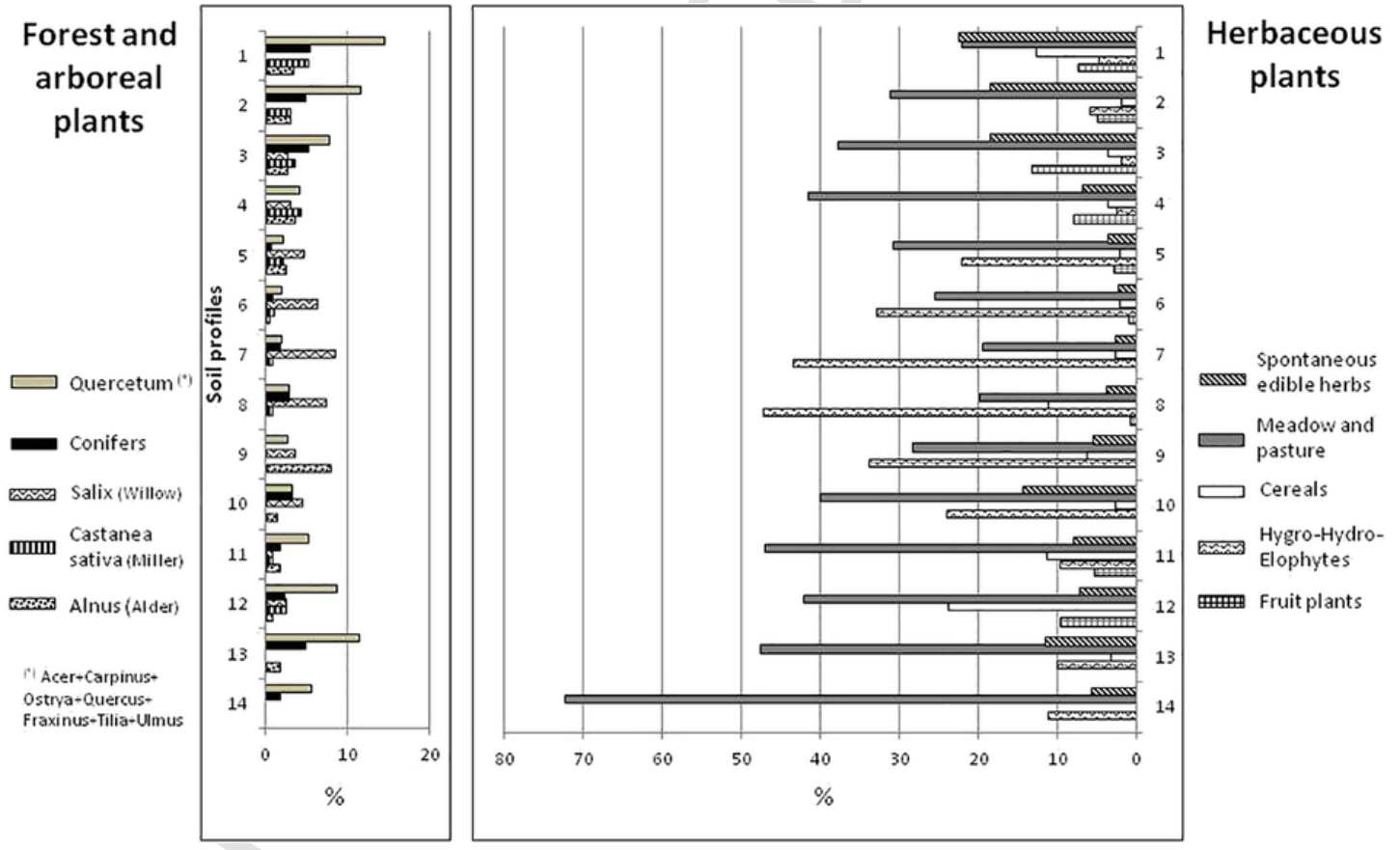

Fig. 5. Pollen concentration of some selected arboreal and herbaceous groups in the stratigraphic sequence.

ginning of the Middle Ages, when the new Savena Vecchio River appeared some kilometres east of the Malalbergo site, inducing the first severe size reduction of the former alluvial basin. After the beginning of the Middle Ages (12th-13th century AD), another severe and effective size reduction of the basin took place, as recorded by Set C (Fig. 2). It was related to very small foothill creeks collected by the Navile artificial canal (Fig. 1) and by agricultural management of the surrounding plain areas. A further basin size reduction and shape change was possibly induced by a new avulsion of the Savena River around the first half of the 16th century $\mathrm{AD}$, generating the Savena Abbandonato that was active between 1561 and $1776 \mathrm{CE}$ (Fig. 1).

Therefore, for at least five centuries, the restricted basin appeared as a narrow corridor open towards the north up to the Po River of Ferrara. At the beginning of the 17th century $\mathrm{AD}$, this narrow landscape unit was further reduced in size by a new Reno River course (not shown in Fig. 1) flowing along a transverse W-E axis, contributing to generate Set B (Fig. 2). Finally, after the first half of the 18th century $\mathrm{AD}$, the birth (1751 CE) of today's Reno course occurred and its devel- 
opment (after the 1776 CE) newly reduced the size of the former alluvial basin to its present very small sub-rounded shape (Fig. 1), inducing the Set A sedimentation (Fig. 2).

In summary, the more superficial deposits are obviously related to the Reno River, which delivered a high amount of sediments from its catchment located in the geologically active domains of the Apennine, which includes easily weatherable sedimentary rocks. The scenario appeared more complex in the Middle Ages, when swamps and marshes captured water of Apennine river courses, as confirmed by the widespread presence of peaty deposits in soil sequences and pollen, indicating hydromorphic conditions. Stratigraphic analogies in neighbouring sites corroborate this hypothesis (Bianchini et al., 2014). The low sedimentation rates that characterise the time interval between the Middle Age and Bronze Age reflect the occurrences of a sui generis depositional hiatus, lasting from the death of the Bronze Age Po River palaeo-branch (see next paragraph) and the death of the Roman Age Reno river, hence including a relative stabilisation of the hydrographic network during the Roman times. Coherently, soil profiles related to this time interval are better developed and pollen investigation indicates the presence of meadows and cereals.

The presented ${ }^{14} \mathrm{C}$ dataset perfectly fits with the above picture and allows us to reconstruct an age-depth model, as shown in Fig. 6. The sedimentation rates ranged between 0.7 e $7 \mathrm{~mm} / \mathrm{y}$, with a value of $1.6 \mathrm{~mm} / \mathrm{y}$ during the Bronze Age. In the uppermost $2 \mathrm{~m}$ of the stratigraphic sequence, the sediment rates could have been even higher (possibly up to $11 \mathrm{~mm} / \mathrm{y}$ ). On the other hand, the existence of at least one diastemic time interval between the Bronze and Roman ages is clearly evidenced by the "flat plateau" of the age-depth diagram. During this long time frame, the birth and the slow growth of the - still far - Roman age Reno River was comprised.

\subsection{Insights on a Bronze Age palaeo-Po southern branch}

Previous stratigraphic logs performed in the Malalbergo surroundings highlighted the existence of sediments characterised by high quartz/feldspar ratios possibly representing more mature (i.e., highly reworked) Po River sediments, sporadically interlayered with more common Reno River sediments (Cibin and Segadelli, 2009). Coherently, soil 12 shows the high $\mathrm{Cr}$ affinity of the Po River sediments, a characteristic well known in the literature (Amorosi, 2012; Bianchini et al., 2002, 2012, 2013). This Cr enrichment is related to the presence of mafic (and ultramafic) rocks outcropping in the Po River basin, which during the weathering process, release clastic particles comparatively enriched in siderophile trace elements ( $\mathrm{Cr}$, in particular). It is interesting to highlight that most of the Malalbergo samples correspond perfectly with the composition of the Reno River alluvial sediments, whereas only the samples pertaining to soil 12 recall the composition of Po River sediments. It must be stressed that soil 12, despite the paucity of carbonate, is comparatively enriched in Sr, which is an addi-

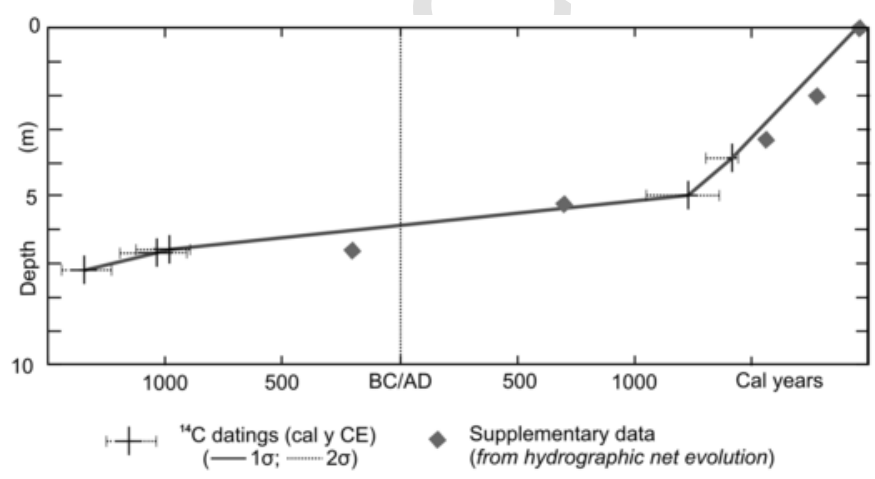

Fig. 6. Age-depth model of the stratigraphic sequence. Chronological supplementary data (black squares) are directly derived by the hydrographic history resumed in the text (§ 5.2). tional proxy indicating the Po River affinity of the parent material (Amorosi and Sammartino, 2007), due to the presence of Sr-bearing mineral phases (plagioclase, pyroxenes, amphiboles) that are related to the weathering of the mentioned mafic rocks (Amorosi, 2012; Bianchini et al., 2012, 2013).

It must be preliminarily stressed that the natural model of the Po River strongly differed from that of today, which consists of a unique, large river flowing into the sea with a lobate delta complex (Castiglioni et al., 1997). In fact, before 1604 CE (Ciabatti, 1966), the Po River was always formed by at least two or even more independent branches each characterised by its own cuspate-delta apparatus. These branches were tens of kilometres apart from one another and their diverging point was located upstream at least $100 \mathrm{~km}$ from the Adriatic Sea coastline.

For a better understanding of sediments having different provenances, the extension of the Po River and its tributaries influence zones (i.z.) sensu Allen (1965) is drafted in Fig. 7.

At the transition area (TA) between the respective i.z., the hydraulic/ hydrographic connectivity between the Po River and its tributaries could variously take place through time. During the Late Holocene, the connection of Po River with its tributaries was mainly driven by the size increase of the respective alluvial ridges and by the action of the alluvial fans, capable of shifting the river confluences (Cremonini, 2010, 2017; Cremaschi and Storchi, 2017). Therefore, the TA represented a diachronic interaction zone of tributaries and collector river domains. In TA, from time to time, the location of the effective i.z. boundary was moving, allowing the allocation of the Po or Apennine river courses, alternatively. For this reason, the existence of thin Po river deposits within Apennine sediments is per se not surprising, as it can also be observed in other areas surrounding the currently active Po River course (Cremonini, 2001; Cremaschi et al., 2006; Bianchini et al., 2014). In fact, the Malabergo site lies $20 \mathrm{~km}$ south of the Po River bed, but is still located inside the influence zones of both Po and Reno rivers. The parent material of Soil 12 was very thin- and fine-grained, suggesting deposits linked to a distal facies of a large crevasse system. The location of the river palaeo-course that generated such a kind of deposit could have been located $2-5 \mathrm{~km}$ north of the study-site, in an area where the palaeo-riverbed is currently buried by more recent sediments (Bianchini et al., 2014). This hypothesis is consistent with the fact that flanks of the Po River alluvial ridges are, on average, very narrow (1.5-2 km: Cremonini, 1988; Castiglioni et al., 1997), together with a number of big crevasse systems spilling out up to $3 \mathrm{~km}$ beyond the lower boundary of the main riverbed alluvial ridge. The unique evidence of such palaeo-Po has been envisaged $30 \mathrm{~km}$ WNW of the Malalbergo site (Fig. 7, left side of track A). It consists of a still outcropping meandering river trunk, known in the literature as palaeo-Po of Barchessoni, that was already active before the end of the Middle Bronze Age (1330 BCE) and continued up to the Final Bronze Age/First Iron age limit (1000-900 BCE; Balista, 2007). A possible palaeo-delta related to the hypothesized Bronze age Po River is shown at the point B area in Fig. 7.

\subsection{Anthropogenic evidences}

The soil profile 12 and the top of soil profile 13 (AC horizon) correspond with the anthropogenic deposits of the Bronze Age, and could be classified as "Terric Anthrosols" according to the WRB taxonomy (IUSS Working Group WRB, 2014).

The horizon 13AC was the top of Apenninic fluvial deposits upon which the settlement took place. The top of soil 13 can be therefore interpreted as an early Bronze Age surface. Notably, the Po River sediments covered this surface and can be ascribed to one (or more) flood event(s) and were continuously affected by human activities that ultimately led to the development of anthropogenic soil horizons. The Anthrosol 12 is therefore a "cultural layer", plausibly reworked by the use of fine earthen material for plastering the huts' walls. Deposits were 


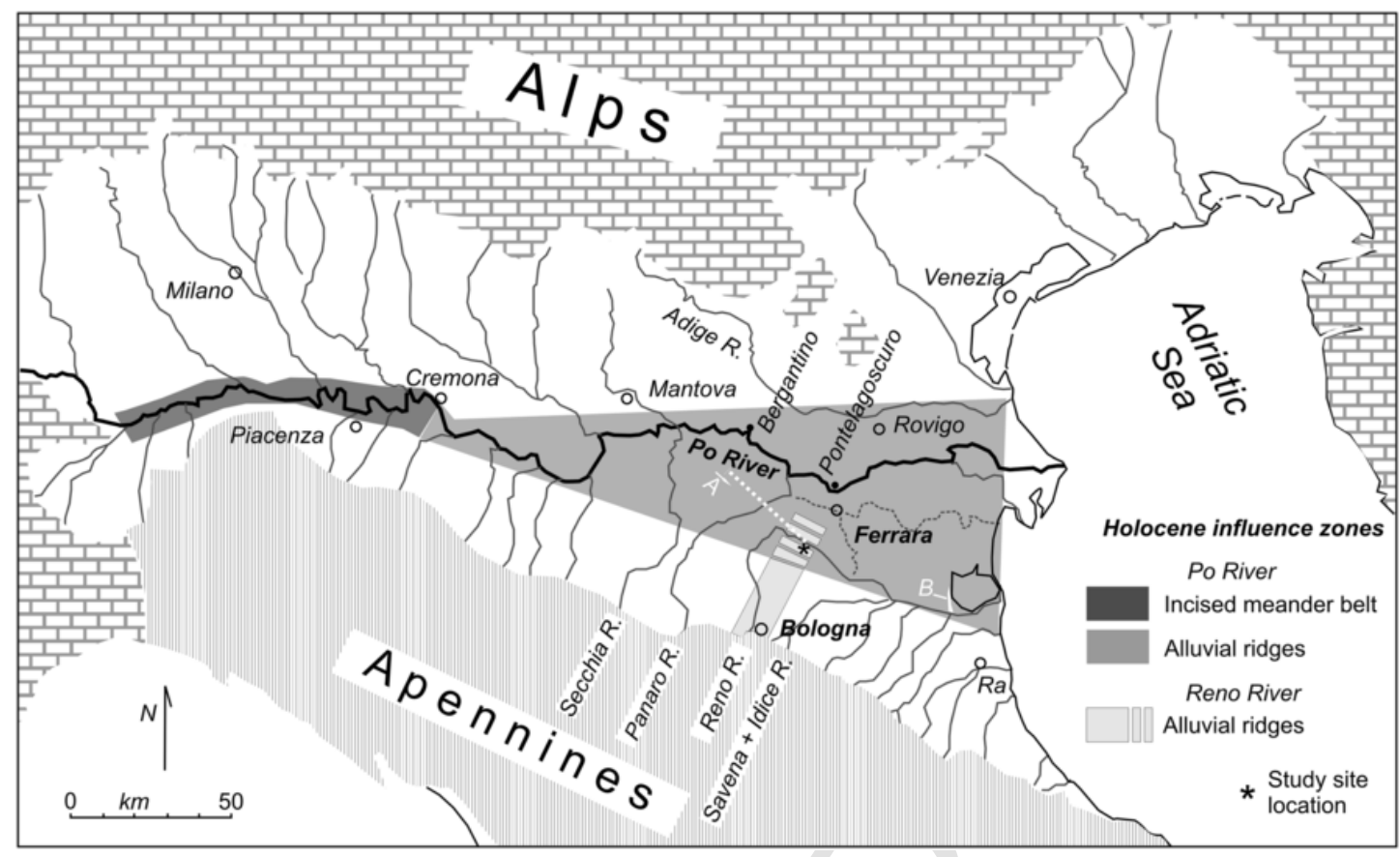

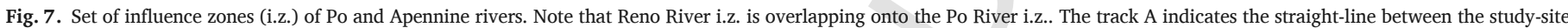
and the nearest - outcropping - Bronze Age Po River palaeo-meander. The possible palaeo-delta related to the hypothesized Bronze Age Po River is tentatively shown in point B.

successively relocated and smoothed at any reconstruction phase. The source area of the building materials was possibly in the near-site fringe of the village where the silty sediments were delivered by a Po River branch.

Soil 12 includes pollen related to meadows and pastures, as well as cereal cultivation (wheat and barley; Bottema, 1992), whereas the aquatic species attain a minimum value, thus suggesting the impact of human settlement on the local environment (Behre, 1981). Notably, Soil 12 is also characterised by high contents of $\mathrm{P}$ and chalcophile elements, such $\mathrm{Cu}$ and $\mathrm{Zn}$. This very high metal concentration is not recorded in any other layer of the stratigraphic log, and it is decidedly higher than the natural background of the surrounding geographic area (Amorosi et al., 2014). This implies an anthropogenic input, likely due to local metal working, plausibly performed in some areas of the village in open-air furnaces with no control in the emission rates and including fine waste dispersal (e.g., Small et al., 1981) that could have been responsible for the widespread occurrence of the recorded metal pollution.

The high concentrations of $\mathrm{Cu}$ and $\mathrm{Zn}$, with only minor traces of $\mathrm{Sn}$, suggest the use of alloys of brass rather than bronze. This might not be that astonishing if the wide compositional range of the ancient copper alloys is considered (e.g., Phillips, 1922). It is impossible to state if local metal working used ingots coming from outer areas, or implied in situ smelting of raw metal-bearing minerals. The observed $\mathrm{Cu}-\mathrm{Zn}$ enrichments could suggest the smelting of sulphides such as chalcopyrite and sphalerite (blenda) that could be retrieved by ore-deposits in the Bologna Apennines (Garuti and Zaccarini, 2005) or in the Southern Alps (Nimis et al., 2012). The presence of Sn could indicate further supplying areas, possibly facilitated by the presence of the active Po River branch easily connecting the site with the Adriatic Sea.

\section{Conclusions}

The presented multi-approach investigation of a stratigraphic sequence located in the alluvial plain at the transition zone between the Po and Apennine river domains highlighted a number of fresh insights that provide new hints for archaeological studies.
An outcome of the study is that the site was involved in sedimentation processes connected with two fluvial systems. The sediments of the Apennine provenance conveyed by the Reno River were largely predominant, whereas sediments of Padanian affinity, related to an unknown Po River course, are totally subordinate and confined only in Soil 12, i.e., coeval to the Bronze Age anthropogenic deposits. This southern Po River palaeo-course generated crevasse systems that delivered sediments around the buried archaeological site. The existence of such a palaeo-river, probably having its own delta along the Adriatic coastline, is crucial to understand the physiographic relationships linking the Po and Apennine Rivers at a multi-millennial time scale. Furthermore, it discloses new scenarios for the Bronze Age human settlement in the Po Plain and the related historical interpretations. The Po River played a key role in the spatial organisation of human settlements, providing a possible route of communication (cross-cultural trade and technical exchange), and a source of water and food. Further studies will be devoted to the discovery of additional evidences of such palaeo-rivers in the neighbouring areas, as a strategy to discover other settlements and to reconstruct the pre-protohistoric evolution within Northern Italy. In general, these results reinforce the potential of systematic multidisciplinary studies of sediments to support archaeological investigations in order to understand the relationship between climate, environment, and human societies.

Supplementary data to this article can be found online at https:// doi.org/10.1016/j.catena.2019.01.025.

\section{Acknowledgements}

The authors wish to thank Drs. Tiziano Trocchi and Paolo Boccuccia (Soprintendenza Archeologia, Belle Arti e Paesaggio, Città Metropolitana di Bologna) for the opportunity of studying the stratigraphic sequence during the archaeological excavation of Malalbergo-Ponticelli and for the permission of publishing the set of ${ }^{14} \mathrm{C}$ datings funded by the Soprintendenza Archeologia, Belle Arti e Paesaggio, Città Metropolitana di Bologna. The authors thank Dr. Silvia Marvelli (Laboratorio Archeoambientale CAA Giorgio Nicoli di S. Giovanni in Persiceto-Bologna) for the important help given during the pollen analyses and Dr. Renzo Tassinari (University of Ferrara) for the XRF analyses. 
over, the authors thank Knut Kaiser, an anonymous Reviewer, and the Editor Markus Egli for the constructive comments that improved earlier versions of the manuscript.

\section{References}

Agatova, R., Nepop, R.K., Bronnikova, M.A., Slyusarenko, I.Y., Orlova, L.A., 2016. Human occupation of south eastern Altai highlands (Russia) in the context of environmental changes. Archaeol. Anthropol. Sci. 8, 419-440.

Allen, J.R.L., 1965. A review of the origin and characteristics of recent alluvial sediments. Sedimentology 5, 89-191.

Amorosi, A., 2012. Chromium and nickel as indicators of source-to-sink sediment transfer in a Holocene alluvial and coastal system (Po Plain, Italy). Sediment. Geol. 280, 260-269.

Amorosi, A., Sammartino, I., 2007. Influence of sediment provenance on background values of potentially toxic metals from near-surface sediments of Po coastal plain (Italy). Int. J. Earth Sci. 96, 389-396.

Amorosi, A., Guermandi, M., Marchi, N., Sammartino, I., 2014. Fingerprinting sedimentary and soil units by their natural metal contents: a new approach to assess metal contamination. Sci. Total Environ. 500-501, 361-372.

Balista, C., 2007. Le dinamiche formative degli antichi dossi al confine fra le province di Modena, Mantova e Ferrara: il paleoambiente insediativo delle terramare, la posizione stratigrafica del paleoalveo dei barchessoni e l'evoluzione paleoidrografica della destra secchia fra l'età del Bronzo e l'età del Ferro. Padusa 43, 121-147.

Balista, C., Cattani, M., Guerra, L., Maini, E., Marcassa, P., Marchesini, M., Marvelli, S., Rinaldi, L., Zuffi, S., 2018. L'abitato di Cà Spadolino di Coccanile (Copparo, FE) e il popolamento lungo i rami meridionali del delta del Po nell'Età del Bronzo. Padusa $51-54,161-220$

Behre, K.-E., 1981. The interpretation of anthropogenic indicators in pollen diagrams. Pollen Spores 23, 225-245.

Berglund, B.E., Ralska-Jasiewiczowa, M., 1986. Pollen analysis and pollen diagrams. In: Berglund, B.E. (Ed.), Handbook of Holocene Palaeoecology and Palaeohydrology. Wiley, Chichester, pp. 455-484.

Bernabò, Brea M., Cardarelli, A., Cremaschi, M. (Eds.), 1997. Le Terramare. La più antica civiltà padana. Milano, (801 p.).

Bianchini, G., Laviano, R., Lovo, S., Vaccaro, C., 2002. Chemical-mineralogical characterisation of clay sediments around Ferrara (Italy): a tool for an environmental analysis. Appl. Clay Sci. 21, 165-176.

Bianchini, G., Natali, C., Di Giuseppe, D., Beccaluva, L., 2012. Heavy metals in soils and sedimentary deposits of the Padanian Plain (Ferrara, northern Italy): characterisation and biomonitoring. J. Soils Sediments 12, 1145-1153.

Bianchini, G., Di Giuseppe, D., Natali, C., Beccaluva, L., 2013. Ophiolite inheritance in the Po Plain sediments: insights on heavy metals distribution and risk assesment. Ofioliti 38, 1-14.

Bianchini, G., Cremonini, S., Di Giuseppe, D., Vianello, G., Vittori Antisari, L., 2014. Multiproxy investigation of a Holocene sedimentary sequence near Ferrara (Italy): clues on the physiographic evolution of the eastern Padanian Plain. J. Soils Sediments 14, 230-242.

Blackwell, P.G., Buck, C.E., Reimer, P., 2006. Important features of the new radiocarbon calibration curves. Quat. Sci. Rev. 25, 408-413.

Boccaletti, M., Martelli, L., 2004. Carta sismo-tettonica della Regione Emilia-Romagna, scala 1:250.000 e note illustrative., Selca, Firenze.

Borgatti, L., Bracci, A.E., Cremonini, S., Martinelli, G., 2012. Searching for the effects of the May-June 2012 Emilia seismic sequence (northern Italy): medium-depth deformation structures at the periphery of the epicentral area. Ann. Geophys. 55, 717-725.

Bottema, S., 1992. Prehistoric cereal gathering and farming in the near east: the pollen evidence. Rev. Palaeobot. Palynol. 73, 21-33.

Bronk Ramsey, C., 2001. Development of the radiocarbon program OxCal. Radiocarbon 43, 355-363.

Calcagnile, L., Quarta, G., D'Elia, M., 2005. High resolution acceleratorbased mass spectrometry: precision accuracy and background. Appl. Radiat. Isot. 62, 623-629.

Carannante, S., Argnani, A., Massa, M., D'Alema, E., Lovati, S., Moretti, M., Cattaneo, M., Augliera, P., 2015. The May 20 (Mw 6.1) and 29 (Mw 6.0), 2012, Emilia (Po Plain, northern Italy) earthquakes: new seismotectonic implications from subsurface geology and high-quality hypocenter location. Tectonophysics 655, 107-123.

Cardarelli, A., 2010. The collapse of the Terramare culture and growth of new economic and social systems during the late bronze age in Italy. Scienze dell'Antichità 15, 449-520.

Castiglioni, G.B., Biancotti, A., Bondesan, M., Castaldini, D., Ciabatti, M., Cremaschi, M., Bavero, V., Pellegrini, G.B., 1997. Carta geomorfologica della Pianura Padana, scala 1:250.000. Selca, Firenze, 6 sheets.

Cattani, M., 2008. La Media Età del Bronzo nell'area tra Panaro e Rreno (Province di Modena e Bologna). Progetto per una ricostruzione del paesaggio. Ipotesi di Preistoria. 1, 211-250, (ISSN 1974-7985).

Cerrina Feroni, A., Martelli, L., Martinelli, P., Ottria, G., 2002. Carta geologico-strutturale dell'Appennino emiliano-romagnolo in scala 1:250.000. Regione Emilia-Romagna C.N.R., Pisa. S.EL.CA., Firenze.

Ciabatti, M., 1966. Ricerche sull'evoluzione dell'antico Delta Padano. Giorn. Geol. 34/2, $27-406$.

Cibin, U., Segadelli, S., 2009. Note illustrative della Carta Geologica d'Italia alla scala 1: 50000, Foglio 203 - Poggio Renatico, (104 p.).

Cocchi Genick, D. (Ed.), 1995. Aspetti culturali della media età del Bronzo nell'Italia centro meridionale. Firenze. 1995, (480 p.).
Corbeau, C., Simeoni, U., Melchiorre, M., Rodella, I., Utizi, K., 2015. Regional variability of coastal dunes observed along the Emilia-Romagna littoral, Italy. Aeolian Res. 18 169-183.

Cremaschi, M., 1997. Terremare e paesaggio padano. In: Bernabò Brea, M., et al. (Eds.), Le Terramare. La più antica civiltà padana. pp. 107-125.

Cremaschi, M., Storchi, P., 2017. Aspetti geomorfologici del tracciato della via Aemilia fra Secchia ed Enza. In: Cantoni, G., Capurso, A. (Eds.), On the Road. Via Emilia 187 a.C.-2017 pp. 208-216.

Cremaschi, M., Pizzi, C., Valsecchi, V., 2006. Water management and land use in the terremare and a possible climatic co-factor in their abandonment: the case study of the terramara of Poviglio Santa Rosa (northern Italy). Quat. Int. 151, 87-98.

Cremonini, S., 1988. Specificità dell'Alto Ferrarese nella problematica evolutiva dell'antica idrografia padana inferiore. In: Berti, F., Gelichi, S., Steffè, G. (Eds.), Bondeno ed il suo territorio dalle origini al Rinascimento. Bologna. pp. 17-24.

Cremonini, S., 1991. Una "finestra geomorfica" d'età classica nella pianura bolognese. Inquadramento analitico del gruppo morfologico del Reno antico. Cremonini S. (a cura di), "Romanità della Pianura. L'ipotesi archeologica a S. Pietro in Casale come coscienza storica per una nuova gestione del territorio", Atti Giornate di Studio, 7/8 Aprile 1990, Bologna. 243-301.

Cremonini, S., 1992. Il torrente Savena oltre i limiti dell'analisi storica. Un esempio di "Archeologia fluviale". Atti e Memorie d. Deputazione di Storia Patria per le Province di Romagna. 42, 159-205

Cremonini, S., 1994. Autopsia di una rotta fluviale. Note e riflessioni in margine all'evento del 1990 occorso nel fiume Reno bolognese. Il Carrobbio. 19/20, 339-362.

Cremonini, S., 2001. Nuovi dati per l'evoluzione paleoambientale recente da una stratigrafia centropadana (Fossa di Concordia, Prov. Modena). In: Calzolari, M., Giordani, N. (Eds.), L'insediamento preistorico e romano di Corte Vanina (Località Fossa di Concordia). Materiali per una storia di Concordia sulla Secchia 3, pp. 37-45.

Cremonini, S., 2010. Morfologie d'alveo e morfogenesi nella media pianura padana: il caso del Panaro nell'età del Bronzo. In: Cattani, M., Marchesini, M., Martelli, S. (Eds.), Paesaggio ed economia nell'età del Bronzo: la pianura bolognese tra Samoggia e Panaro. Bologna. pp. 27-33.

Cremonini, S., 2017. Note di geomorfologia della pianura tra Panaro e Samoggia. In: Campagnari, S., Neri, D. (Eds.), Alle soglie della romanizzazione: storia e archeologia di Forum Gallorum. S. Giovanni in Persiceto (BO) pp. 41-44.

Cremonini, S., Labate, D., Curina, R., 2013. The late-antiquity environmental crisis in Emilia region (Po river plain, northern Italy): geoarchaeological evidence and paleoclimatic considerations. Quat. Int. 316, 162-178.

Desantis, P., Steffè, G. (Eds.), 1995. L'insediamento terramaricolo di Pilastri (Bondeno Ferrara). Prime fasi di una ricerca. Firenze, (104 p.).

Di Giuseppe, D., Bianchini, G., Faccini, B., Coltorti, M., 2014. Combination of wavelength dispersive X-ray fluorescence analysis and multivariate statistic for alluvial soils classification: a case study from the Padanian Plain (northern Italy). X-Ray Spectrom. 43, 165-174.

Faegri, K., Iversen, J., 1989. Textbook of Pollen Analysis, 4th edition John Wiley \& Sons, Chichester, (328 p.).

Fantoni, R., Franciosi, R., 2010. Mesozoic extension and Cenozoic compression in Po Plain and Adriatic foreland. Rend. Fis. Acc Lincei 21, 197-209.

Fiorentino, G., Caracuta, V., Calcagnile, L., D'Elia, M., Matthiae, P., Mavelli, F., Quarta, G. 2008. Third millennium B.C. climate change in Syria highlighted by carbon stable isotope analysis of ${ }^{14} \mathrm{C}$-AMS dated plant remains from Ebla. Palaeogeogr. Palaeoclimatol. Palaeoecol. 266, 51-58.

Fontana, A., Mozzi, P., Marchetti, M., 2014. Alluvial fans and megafans along the southern side of the Alps. Sediment. Geol. 301, 150-171.

Gabusi, R., Miari, M., Trocchi, T., 2018. Ponticelli di Malalbergo. In: Quem, Ante (Ed.), Un abitato del II millennio a.C. e le successive trasformazioni del territorio. p. 136, (ISBN 978-88-7849-134-2).

Galli, P., Castenetto, S., Peronac, E., 2012. May 2012 Emilia earthquakes (MW 6, northern Italy): macroseismic effects distribution and seismotectonic implications. Alp. Mediterr. Quat. 25, 105-123.

Gangopadhyay, S., Gupta, A.D., Nachabe, M.H., 2001. Evaluation of ground water monitoring network by principal component analysis. Groundwater 39, 181-191.

Garuti, G., Zaccarini, F., 2005. Minerals of Au, Ag, and U in volcanic-rock-associated massive sulfide deposits of the north-ern Apennine ophiolite, Italy. Can. Mineral. 43, 935-950.

Ghielmi, M., Minervini, M., Nini, C., Rogledi, S., Rossi, M., Vignolo, A., 2010. Sedimentary and tectonic evolution in the eastern Po-plain and northern Adriatic Sea area from Messinian to middle Pleistocene (Italy), in nature and geodynamics of the northern Adriatic Lithostere. Rend. Fis. Acc. Lincei 21, 131-166.

Ghielmi, M., Minervini, M., Nini, C., Rogledi, S., Rossi, M., 2013. Late Miocene-middle Pleistocene sequences in the Po plain —northern Adriatic Sea (Italy): the stratigraphic record of modification phases affecting a complex foreland basin. Mar. Pet. Geol. 42, $50-81$.

Horák, J., Janovský, M., Hejcman, M., Šmejda, L., Klír, T., 2018. Soil geochemistry of medieval arable fields in Lovětín near Třešt, Czech Republic. Catena 162, 14-22.

Imai, N., Terashima, S., Itoh, S., Ando, A., 1996. Compilation of analytical data on nine GSJ geochemical reference samples, "sedimentary rock series". Geostand. Newslett. 20, 165-216.

IUSS Working Group WRB, 2014. World reference base for soil resources 2014. In: International Soil Classification System for Naming Soils and Creating Legends for Soil Maps. World Soil Resources Reports No. 106 FAO, Rome.

Lowe, J.J., Accorsi, A.C., Bandini Mazzanti, M., Bishop, A., Van der Kaars, S., Forlani, L., Mercuri, A.M., Rivalenti, C., Torri, P., Watson, C., 1996. Pollen stratigraphy of sediment sequences from crater lakes Albano and Nemi (near Rome) and from the centra Adriatic, spanning the interval from oxygen isotope stage 2 to the present day. In: Memorie Istituto Italiano Idrobiologia. 55, pp. 71-98. 
Marchesini, M., Marvelli, S., Lobietti, A., 2017. The palynology contribution in palaeoenvironmental investigation. A case-study of a Lateglacial-Holocene sedimentary sequence near Bologna (Northern, Italy). EQA 25, 39-47.

Milton, C.J., 2018. Geophysics and geochemistry; an interdisciplinary approach to archaeology in wetland context. J. Archaeol. Sci. Rep. 18, 197-212.

Moore, P.D., Webb, J.A., Collinson, M.E., 1991. Pollen Analysis, 2nd edition Blackwell, Oxford, 1-216.

Muttoni, G., Carcano, C., Garzanti, E., Ghielmi, M., Piccin, A., Pini, R., Rogledi, S., Sciunnach, D., 2003. Onset of major Pleistocene glaciations in the Alps. Geology 31, 989-992.

Nimis, P., Omenetto, P., Giunti, I., Artioli, G., Angelini, I., 2012. Lead isotope systematics in hydrothermal sulphide deposits from the central-eastern Southalpine (northern Italy). Eur. J. Mineral. 24, 23-37.

Pasini, B., 1958. La sistemazione idraulico-agraria delle risaie ferraresi. SATE, Ferrara.

Pastor, A., Gallello, G., Cervera, M.L., de la Guardia, M., 2016. Mineral soil composition interfacing archaeology and chemistry. Trends Anal. Chem. 78, 48-59.

Phillips, G.B., 1922. The composition of some ancient bronze in the dawn of the art of metallurgy. Am. Anthropol. 24, 129-143.

Pieri, M., Groppi, G., 1981. Subsurface geological structure of the Po Plain, Italy. In: Pieri, M., Groppi, G. (Eds.), Progetto Finalizzato Geodinamica. 414, C.N.R, Roma, pp. 1-23.

Pignatti, S., 1982. Flora d'Italia. Edagricole, Bologna.

Schoeneberger, P.J., Wysocki, D.A., Benham, E.C., 2012. Soil survey staff. In: Field Book for Describing and Sampling Soils. Version 3.0. Natural Resources Conservation Service National Soil Survey Center, Lincoln, NE.

Simniškytè-Strimaitienė, A., Selskienė, A., Vaičiūnienè, J., Pakštas, V., Šmigelskas, R., 2017. Tracing archaeology through geochemistry: an example of a disturbed prehistoric hilltop settlement site in South-Eastern Lituania. Interdiscip. Archaeol. VIII, 17-33.
Small, M., Germani, M.S., Small, A.M., Zoller, W.H., 1981. Airborne plume study of emissions from the processing of copper ores in southeastern Arizona. Environ. Sci. Technol. 15 (3), 293-299.

Steffè, G., 1999. Lugo di Romagna (RA). In: Schede di Archeologia dell'Emilia Romagna, Bologna.

Stuiver, M., Polach, H.A., 1977. Discussion: reporting of ${ }^{14} \mathrm{C}$ data. Radiocarbon 19 , 355-363.

Tutin, T.G., Heywood, V.H., Burges, N.A., Valentine, D.H., Walters, S.M., Webb, D.A. (Eds.), 2001. Flora Europaea, vol. 1,2 and 5, 2nd edition, Cambridge University Press, Cambridge, UK.

Vai, G.B., Martini, I.P. (Eds.), 2001. Anatomy of an Orogen. The Apennines and adjacent Mediterranean Basins, London, Kluwer, (633 p.).

Vittori Antisari, L., Bianchini, G., Dinelli, E., Falsone, G., Gardini, A., Simoni, A., Tassinari, R., Vianello, G., 2014. Critical evaluation of an intercalibration project focused on the definition of new multi-element soil reference materials (AMS-MO1 AND AMS-ML1). EQA 15, 41-66.

Vittori Antisari, L., Bianchini, G., Cremonini, S., Marvelli, S., Vianello, G., 2016. Multidisciplinary study of a Lateglacial-Holocene sedimentary sequence near Bologna (Italy) insights on natural and anthropogenic impacts on the landscape dynamics. J. Soils Sediments 16, 645-662.

Vittori, Antisari L., Cremonini, S., Desantis, P., Calastri, C., Vianello, G., 2013. Chemical analysis of ancient anthro-technosols in a bronze up to middle ages archaeological sequence in Bologna (Italy). J. Archaeol. Sci. 40, 3660-3671.

Wentworth, C.K., 1922. A scale of grade and class terms for clastic sediments. J. Geol. 30 377-392.

Woodward, J., Huckleberry, G., 2011. The geoarchaeology of river basin systems: an introduction. Geoarchaeology 26, 611-615. 
The archaeological site of Malalbergo (Ponticelli di Malalbergo) is described by Gabusi et al. (2018). The site was discovered at depth during the construction of a gas pipeline. The archaeological excavation was performed in two trenches $22 \times 7 \mathrm{~m}$ wide, lying $60 \mathrm{~m}$ apart (Supplementary Photos 1 ). The excavation was supervised by Soprintendenza Archeologia dell'Emilia-Romagna during the years 2015-2016. The anthropogenic deposit was found at $7.0 \mathrm{~m}$ depth (Fig. 2, Set E) and had a thickness of 80 to $110 \mathrm{~cm}$. The Malalbergo archaeological site was very rich in ceramic and metallic fragments and in faunal and malacologic remains. It preserved the evidence of a number of huts and trench structures, indicating the peripheral belt of the site. Four constructive phases were recorded, followed in turn by a final dismantling. The thickness of each phase deposit was 20 to $25 \mathrm{~cm}$ on average. In all settlement phases the orientation of anthropogenic structures was the same, i.e., NW/SE and NE/SW. The most ancient phase was characterised by the existence of rectangular wooden huts built on an overhead deck. In the second phase, a hut was built on an earthen compacted platform. The third phase was recorded by an aggrading layer with faunal remains, heated earth, and coarse sherds, referring to some productive activity, without dwellings. Furthermore, a spoliation ditch of a previously existing wooden fence was also recognised. The fourth phase was characterised by the presence of tree uprooting hollows and a wooden floor built along the bank of an artificial ditch. The metallic objects found in the site (Supplementary Photo 2) consist of big pins, daggers and small rings, recalling those typical of the Terramare Culture spread on Emilia territories west of the Malalbergo site, whereas the ceramic production recalls the Grotta Nuova and Subappenninic cultural facies characterising the Romagna area, east of Malabergo, and central Italy (Cocchi Genick, 1995; Bernabò et al., 1997). Thus, the archaeological materials can be tentatively dated back to the Medium and Late Bronze Ages, and the settlement age of the village could be established between the first half of the 15th century BC and the second half of the 13th century BC. The discovery of the archaeological site of Malabergo is very important, because only other two Bronze Age sites are known to exist in the easternmost Po River plain, at Coccanile (Balista et al., 2018) and Pilastri di Bondeno (Desantis and Steffè, 1995) that are located at $30 \mathrm{~km} \mathrm{NW}$ and $40 \mathrm{~km} \mathrm{NE}$ of Malabergo, respectively.

The analyses by XRF of major and trace elements (expressed in $\mathrm{wt} \%$ and $\mathrm{mg} \mathrm{kg}^{-1}$, respectively) of all soil horizons from the two stratigraphic sections (1MAL and 2MAL) are reported in Supplementary Tables 1 and 2, whereas Supplementary Table 3a shows the three components (PC1, PC2 and PC3) obtained by PCA processing. PC1 has a positive loading for all variables except for $\mathrm{SiO}_{2}, \mathrm{CaO}, \mathrm{Na}_{2} \mathrm{O}$ and $\mathrm{Zr}$. PC2 groups the variables $\mathrm{P}_{2} \mathrm{O}_{5}, \mathrm{Cu}, \mathrm{Ni}$ and $\mathrm{Zn}$. PC3 has a high-positive loading for $\mathrm{SiO}_{2}$ and a high-negative loading for LOI. The scores obtained from the factor analysis have been plotted on a binary diagram (PC1 vs. PC2) to evaluate geochemical analogies and differences between the distinct soil horizons (Fig. 3a). In this diagram, a homogeneous grouping of soil samples along a trend line $\mathrm{y}=0.3 \times-0.2$ can be observed, with the exception of four samples, referring to Soil 12 . These outliers have a distinct origin with respect to the other samples.

The enrichment of chalcophile elements such as copper $(\mathrm{Cu})$ and zinc $(\mathrm{Zn})$, suggesting an anthropogenic contribution, can also be observed by aqua regia extraction and ICP-OES determination of trace elements (Supplementary Table 4S; Fig. 4). Despite the different analytical approach, ICP-OES confirms that samples of Soil 12 are completely different from the other ones, having very a high content of $\mathrm{Cu}, \mathrm{Zn}$, and P (Fig. 4a and b). The aqua regia method also highlighted that Soil 12 is comparatively enriched in Sn and Cd (Fig. 4c and d), suggesting the local occurrence of ancient metallurgical activities. 